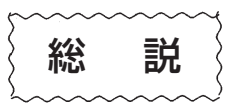

\title{
細菌性溶血性黄㾝
}

\author{
高野倫一* - 松山知正
}

(2020年 3 月23日受付）

\section{Bacterial Hemolytic Jaundice}

\author{
Tomokazu Takano* and Tomomasa Matsuyama \\ Nansei Main Station, National Research Institute of Aquaculture, \\ Japan Fisheries Research and Education Agency, \\ Mie 519-0193, Japan
}

(Received March 23, 2020)

\begin{abstract}
Bacterial hemolytic jaundice (BHJ) was first described in populations of cultured yellowtail, Seriola quinqueradiata in 1980 in Japan. BHJ is now one of the most important diseases of farmed yellowtail. The taxonomic position of the causative agent, Ichthyobacterium seriolicida, was recently determined as a single clade within the order Flavobacteriales and was distinct from the known clades of the family Flavobacteriaceae, Blattabacteriaceae and Cryomorphaceae. Whole genome analysis of the type strain JBKA- $6^{\top}$ revealed that this bacterium harbors a single circular chromosome. Polymorphic analyses of $I$. seriolicida identified four major clusters among $I$. seriolicida isolates, and all belonged to clonal complexes; thus, this bacterium is considered to be recently introduced in Japan. In passive immunization tests, significantly lower mortality was observed in fish that received the serum from a convalescent fish, indicating I. seriolicida is neutralized by the humoral component of the immune system. However, since this bacterium does not grow vigorously in vitro, control measures such as the production of an inactivated vaccine is under development.
\end{abstract}

Key words: Bacterial hemolytic jaundice, Ichthyobacteriaceae, Ichthyobacterium seriolicida, Flavobacteriales, Seriola quinqueradiata

歴史

1980年代はじめから体色が黄色化する病気が養殖ブリ に発生し，1990年ごろまでには九州，四国，紀伊半島沿 岸などの西日本各地のブリ養殖場において “黄㾝症”が 知られるようになった。2 年魚以上の大型魚でも発症し, 当時の死亡率は 5〜20\%であったことが報告されている (反町ら，1993a）。本症の原因は長らく不明であり，餌 料や飼育条件など様々な原因が考えられていた。発生域 が徐々に伝播・拡大していくこと, マクロライド系抗生 物質に効果が認められることなどから伝染性疾病の可能 性も強く疑われていた（反町ら，1993a）。一方，Sakai

\footnotetext{
国立研究開発法人水産研究・教育機構増養殖研究所

* Corresponding author

E-mail: takanoto@fra.affrc.go.jp
}

ら（1989）は，チオバルビッール酸（TBA）価が病魚の 肝臓や筋肉で高くなることを見つけ, 本症への脂質過酸 化の関与を指摘した。和田ら（1989）が害施した病理組 織学的検査ではいくつかの特徵的な病変を観察したもの の, 原因の特定には至らなかった。1990年代に入って反 町ら（1993a）が, 黄疸を発症したブリの血液中に存在 する長桿菌の分離培養，および培養菌を使った感染試験 による黄疸の再現に成功し, 本菌が病原体であることを 報告した。このため現在, 本症には“細菌性溶血性黄 疸 : Bacterial Hemolytic Jaundice (BHJ)” が魚病名とし て選定されている（前野ら，1995）。原因病原体の分類 については，未だに近縁な細菌が見つかっていないこと に加え, 本菌が難培養性であることから解析が難航して いたが, 最近になりIchthyobacterium seriolicida の学名 が付された（Takano et al., 2016）。 


\section{病原体}

病原体は，フラボバクテリウム目 (Flavobacteriales), イクチオバクテリウム科 (Ichthyobacteriaceae) に属す る好気性菌のI. seriolicida である。鞭毛を持たないグラ 么陰性の長桿菌（0.3×4 6 $\mu \mathrm{m} ） （$ Fig. 1) で特徴的な滑 走運動をする（反町ら，1993a； Takano et al., 2016）。 カタラーゼ産生能は無く、オキシダーゼは陽性である (Takano et al., 2016)。化学分類指標となる菌体の主なキ ノン組成はメナキノン-6（MK-6）（95.1９7.9\%）および MK-7 (2.1 4.9\%) であり, 主な菌体脂肪酸組成は $\mathrm{C}_{14: 0}$ (13.4〜20.5\%）および iso-C 15:0 $_{1}(56.5 〜 68.7 \%)$ である (Takano et al., 2016)。

本菌は他の魚病細菌の Flavobacterium branchiophilum, F.columnare, F.hydatis, F.psychrophilum, F.succinicans, Tenacibaculum discolor, T. gallaicum, T. maritimum 拉よ びT. soleae と目レベルで近縁と言えるが, これらの細菌 はいずれもフラボバクテリウム科 (Flavobacteriaceae) に属する。一方，イクチオバクテリウム科の細菌は，現 在までにI. seriolicidaの一属一種しか見つかっておらず, 本菌は分類学的に珍しい。Ichthyobacterium seriolicida の Type strain（基準株）は，1991年10月に香川県下の養 殖ブリから反町氏が分離したJBKA-6 ${ }^{\top}$ であり, American Type Culture Collection（ATCC）には ATCC BAA-2465 として, Japan Collection of Microorganisms（JCM）に は JCM $18228^{\top}$ として寄託登録されている。JBKA-6 ${ }^{\top}$ の ゲノム（GenBank accession no. NZ_AP014564）は，全

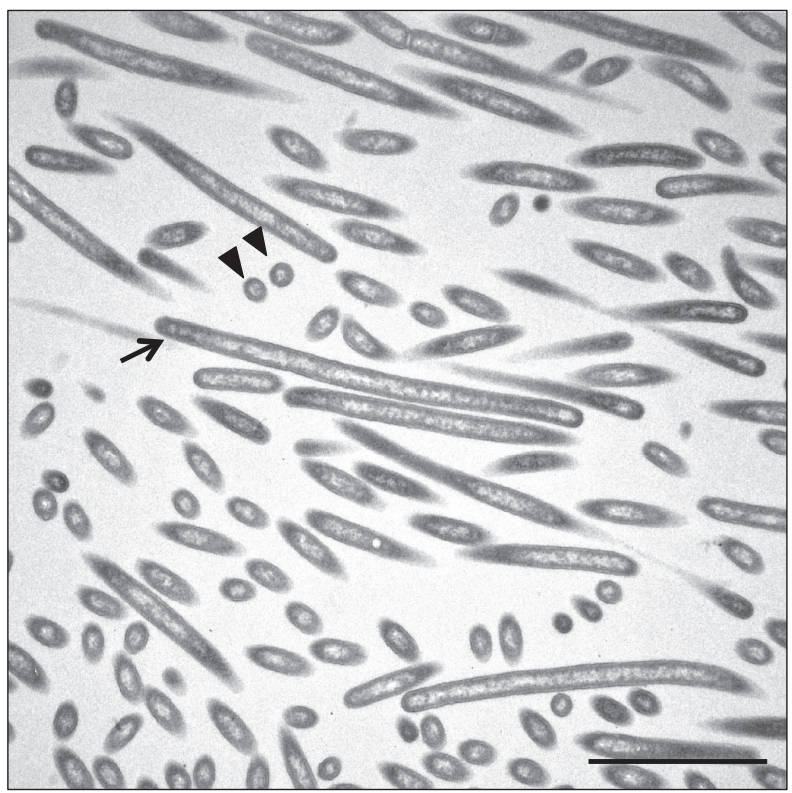

Fig. 1. Cell morphology of Ichthyobacterium seriolicida strain JBKA $-6^{\top}$ observed under transmission electron micrograph (TEM). Ultrathin section shows both lateral (arrow) and vertical (triangle) sections of the bacterial cells. Scale bar $=2.0 \mu \mathrm{m}$.
長が 1,921,407 bp の環状二本鎖 DNA で, G + C 含量は 32.8\%であり，32個の tRNA 領域と 1 つの rRNA オペロ ンが存在する。タンパク質をコードした遺伝子は1,474個 が予測されている。その中には, 本菌の病原性に関わる と考えられる遺伝子が含まれ, Type IX 分泌装置の遺伝 子群や， 2 種類のへモリジン遺伝子が見つかっている (Takano et al., 2017)。本菌には宿主の血球に積極的に付 着する様子が観察できることから（Fig. 2), 宿主細胞へ の付着に関わる遺伝子も病原性を発揮する上で重要であ ると考えられる。

Ichthyobacterium seriolicida の培養には, Leibovitz's L-15 液体培地（L-15）にウシ胎児血清（FBS）を 10\% （v/v）添加したものを標準的に用いる。寒天を添加した 培地では全く増殖しない。 $\mathrm{NaCl}$ の至適濃度は1.6\%（w/ v）であるため, 培養に用いる L-15 培地の $\mathrm{NaCl}$ 終濃度 を1.6\%に調節することが望ましい。至適 $\mathrm{pH}$ は7.0 7.5で ある（lida and Sorimachi, 1994）。FBS の濃度を0〜 20\%まで変化させた場合には，20\%で最も増殖が良くな ることが報告されている（lida and Sorimachi, 1994）。増 殖は L-15 に劣るものの, Eagle's MEM，0.85\%食塩水ま たは $1 / 3$ 海水に $10 \%$ の FBS を添加することで本菌を培養 することができる。しかし，0.85\%食塩水または $1 / 3$ 海水 を使用した場合には連続して継代することは困難である (lida and Sorimachi, 1994)。BHI 寒天培地, 変法バッ ラー寒天培地, ブリ血清またはウシ胎児血清（FCS）を 添加したフレッチャー培地㧍よびコルトフ培地では発育 しない（反町ら，1993a）。Ichthyobacterium seriolicida の増殖は $18 \sim 28^{\circ} \mathrm{C}$ の間で認められ, 至適温度は $26^{\circ} \mathrm{C}$ で ある（Iida and Sorimachi, 1994; Takano et al., 2016）。培 養条件下での増殖は遅くかつ菌体密度もかなり低い。至 適温度下で振晹培養しても, 最大の濁度は0.1〜0.2程度 $\left(\mathrm{OD}_{660}\right)$ であり，培養時間も静止期に達するまでに70時 間以上を要する（Takano et al., 2016）。Tenacibaculum

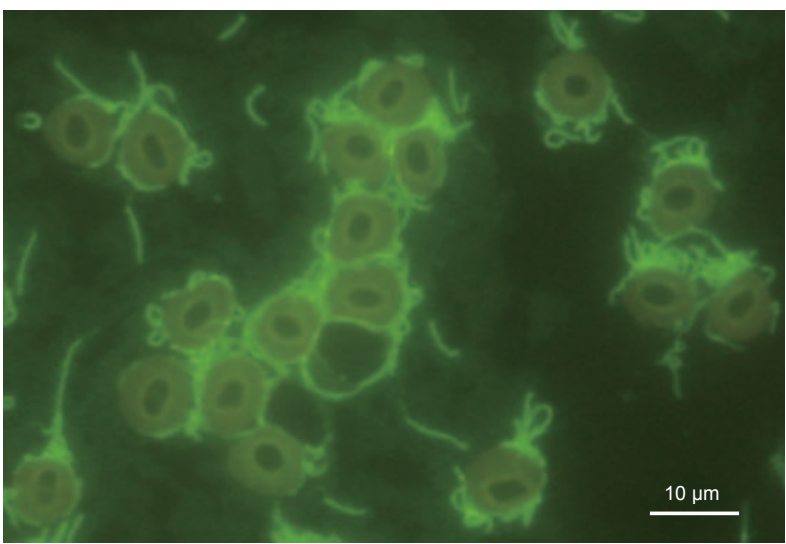

Fig. 2. Microscopy of fluorescently-labeled live cells of JBKA$6^{\top}$ inoculated with the blood cells of yellowtail. Intense adherence of bacterial cells to the blood cells was observed. 


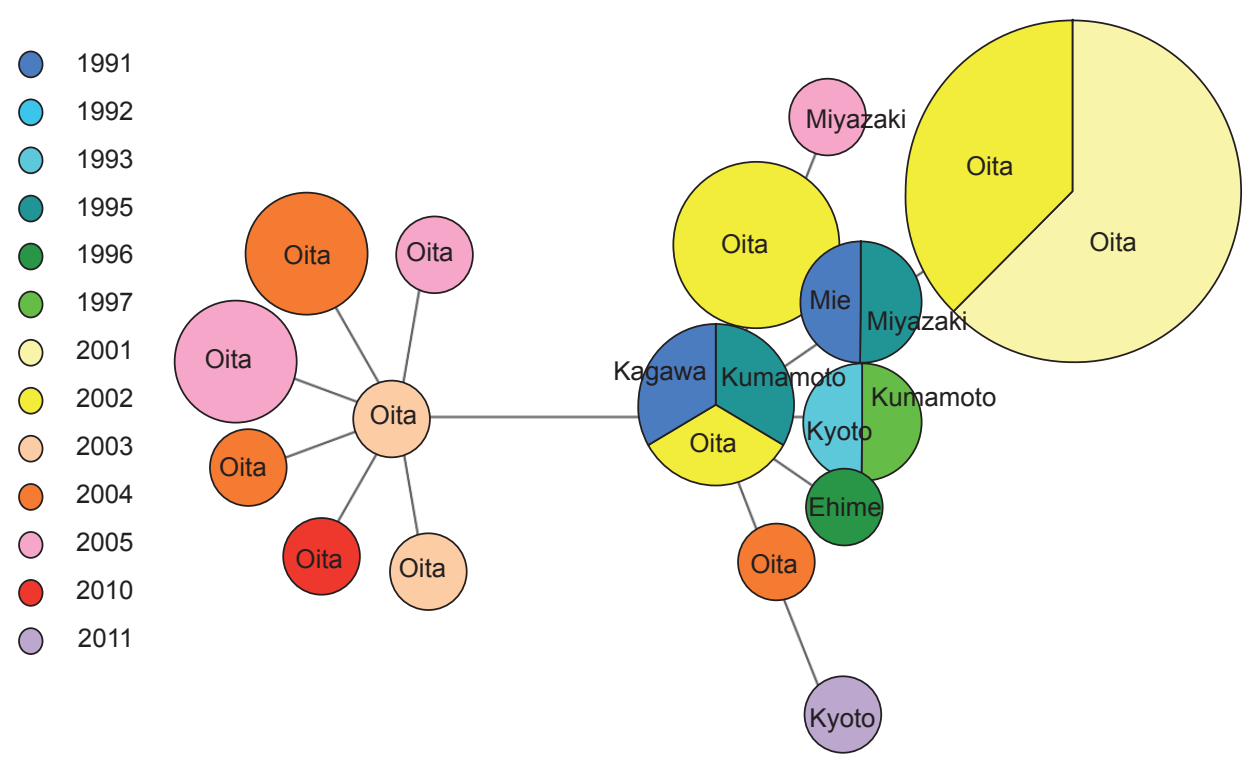

Fig. 3. Minimum spanning tree based on multiple-locus variable-number tandem repeat analysis (MLVA) allelic profiles. The phylogenetic relationship among 31 Ichthyobacterium seriolicida isolates is shown. Each node represents a unique sequence type (ST). The size of the circle is proportional to the number of strains belonging to the STs. The collection locations are indicated in each node. Collection years are indicated by colors.

maritimum での報告（増村・若林, 1977） と同様に, 静 止期に入った本菌を長時間放置すると菌体の球形化が観 察される (未発表)。培養菌液の遠心分離から得られる菌 体ペレットは乳白色を呈するため, フラボバクテリウム 科の細菌のようにカロテノイドやフレキシルビン等の黄 色ないしは橙色の色素を産生しないものと考えられる。

国内の異なる年代や場所から分離したI. seriolicida で実施した amplified fragment length polymorphism (AFLP) 解析や，8 種類のハウスキーピング遺伝子を利 用した multilocus sequence typing (MLST) からは，分 離株の間に多型性を検出できなかったことが報告されて いる（Matsuyama et al., 2017）。ゲノム中の繰り返し配 列を利用した multiple-locus variable-number tandem repeat analysis（MLVA）では，31分離株が16種類の sequence type（ST）に分類されたが，いずれのSTも 1つの clonal complex（クローン集合体）に属すること が明らかになっている (Matsuyama et al., 2017) （Fig. 3）。分離株間で遺伝的多型性がそしいことは, 何らかの 原因で国内に持ち込まれた菌株が拡散した。あるいは非 病原性細菌が, 何らかの理由で病原性を獲得し本症の原 因となった可能性を示唆する。ブリ養殖が本格的に産業 化したのは1950年代であり，その後30年も経過してから BHJ は顕在化したことから，本菌がもともと国内のブリ 養殖環境中に存在したとは考えにくい。1980年代には東 シナ海産および南シナ海産のブリ種苗を輸入した記録が 残されており，海外から本菌が持ち込まれた可能性も考 えられる（Matsuyama et al., 2017)。ただし，海外にお
ける BHJ 症発生例はこれまでのところ無い。

\section{発症魚}

BHJ は養殖ブリおよび養殖ヒラマサで発生が確認され ているが（柳ら，2016），養殖カンパチや天然魚での発 生報告はない。

発症魚には緩慢な遊泳と体色黒化が認められ，摂餌が 不活発になる。へマトクリット值は20\%前後まで低下す るため, 鰓の螁色や変色を伴う貧血症状が認められる (反町ら，1993a)。Ichthyobacterium seriolicida に感染し た魚は，溶血性貧血を起こし血漿中の総ビリルビン量が 急激に上昇する（反町ら，1993a）。これは，溶血物中の ヘモグロビンに起因する連鎖的な酸化ストレスがへムオ キシゲナーゼを誘導しビリルビンの過剩合成が生じるた めで，その結果として黄疸を発症すると考えられている (Sakai et al., 1998 ; 伊東ら, 2000)。健康魚では白色で あるはずの腹部が発症魚では顕著に黄色化することから， 本症は容易に確認することができる（Fig. 4）。吻部や眼 窩にも黄色化が認められる（和田ら，1989；反町ら， 1993a）。肝臓求よび脾臟は, 健康魚のそれと比較してそ れぞれ約 3 倍および約 6 倍程度に著しく腫大する（反町 ら，1993a）。前野ら（1995）が実施した実験感染魚にお ける病理組織学的検査からは, 肝臟のうっ血, 肝細胞お よび肝静脈血管内皮細胞の変性，細尿管上皮細胞抢よび 糸球体の壊死，脾内血管のうっ血，脾臟䯣質部の核濃縮 を伴う広範囲な壊死，溶血像などが報告されている。 

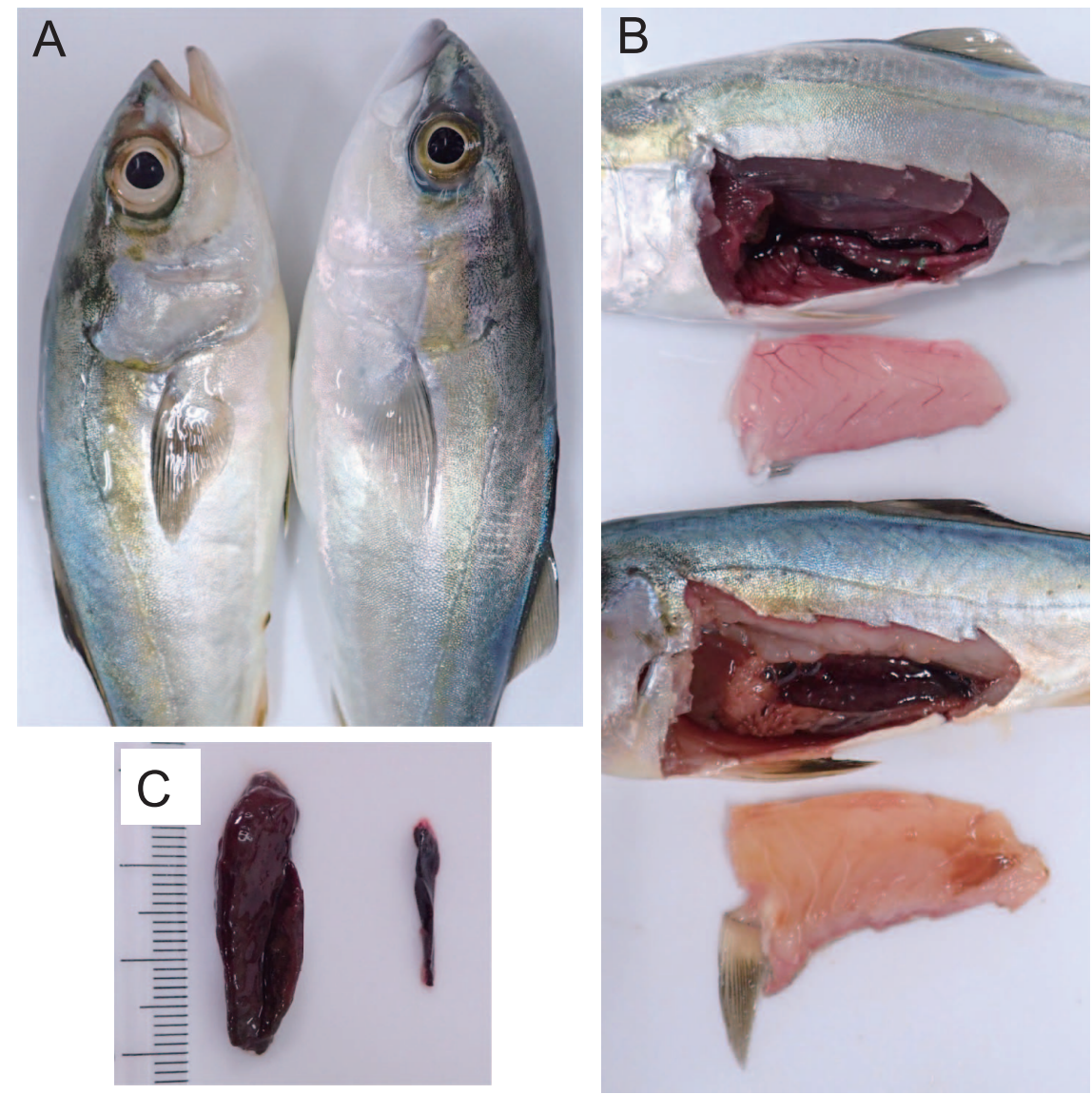

Fig. 4. External symptoms and necropsy of yellowtail experimentally infected with Ichthyobacterium seriolicida. A) Yellow coloration of the skin was observed in infected fish (left), but not in healthy fish (right). B) Necropsy of infected fish (lower) and healthy fish (upper). Intra-abdominal surfaces and lateral muscle of the infected fish showed yellowish-brown color. Spleen was obviously enlarged in infected fish. The stomach was removed from both fish to observe the spleen. C) Size comparison of the excised spleen tissues between I. seriolicida-infected fish (left) and healthy fish (right).

診

\section{断}

養殖ブリにおいて黄疸症状を呈する感染症は少なく， 先に述べた外部所見はBHJ 発症の推定に役立つ。血液塗 抹標本をギムザ染色（反町ら，1993a）やディフ・ク イック染色（Fig. 5) することで血球の周辺に多数の長 桿菌を認めることができる。Tenacibaculum maritimum 等の長桿菌との混同を避けるため, I. seriolicidaの 16S rDNA に対して特異的な PCR プライマー（三井ら, 2004）で分離菌を確認することが望ましい。本菌を分離 する場合には，瀕死魚から無菌的に採取した血液を先に

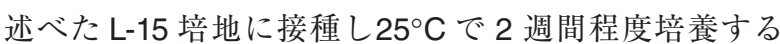
(反町ら，1993a）。本菌は非常に細く観察しづらいため, 市販の蛍光試薬の LIVE/DEAD BacLight Bacterial Viability Kit（Molecular Probes）で染色し蛍光顕微鏡下で観察す ることで細胞の形態や運動性を鮮明に観察することがで きる（Fig. 6)。

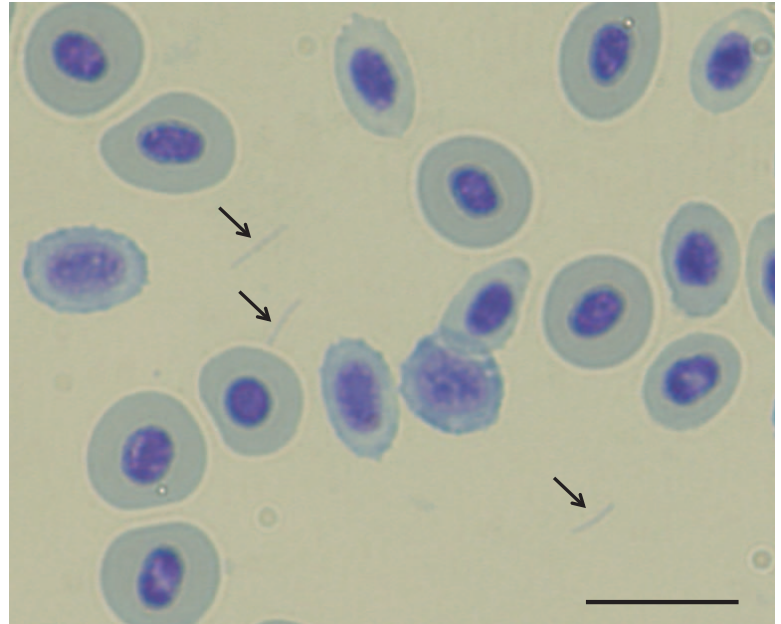

Fig. 5. Light micrograph of blood smear from an artificially infected fish at 7 days post-infection. The smear was fixed and stained with Dif-Quick stain. Long rodshaped bacterial cells were faintly stained (arrow). Scale bar $=10.0 \mu \mathrm{m}$. 


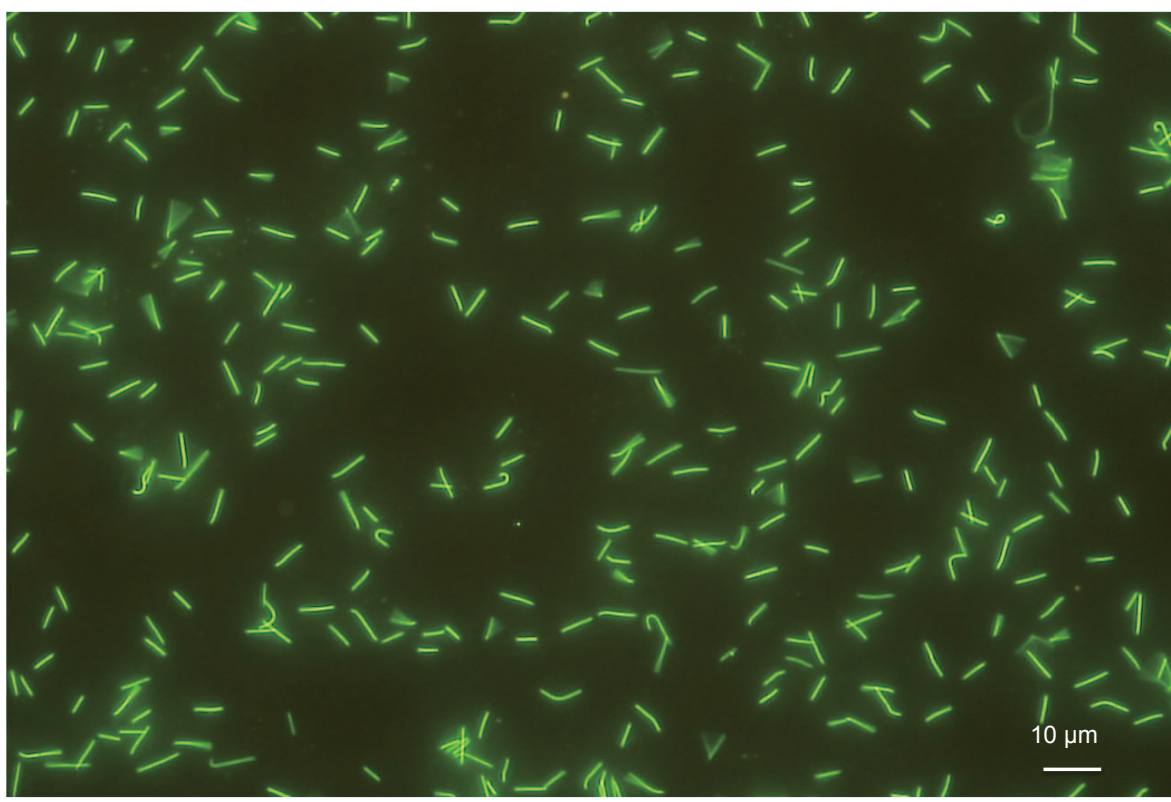

Fig. 6. Morphology of fluorescently-labeled cells of JBKA-6 ${ }^{\top}$ on a glass slide.

\section{防 除 対 策}

本菌については，尾静脈注射および腹腔内注射のみな らず浸漬法でも感染試験が成立することが報告されてい ることから (反町ら，1993a），病魚を頻繁に取り上げる ことは感染の拡大を防ぐために有効であると考えられる。 各種抗菌性物質に対する I. seriolicida の最小発育阻止濃 度（minimum inhibitory concentration, MIC）はそれぞれ， アンピシリン (0.125〜0.2 $\mu \mathrm{g} / \mathrm{mL})$, エリスロマイシン $(0.2 \mu \mathrm{g} / \mathrm{mL})$, エンボン酸スピラマイシン $(0.78 \mu \mathrm{g} / \mathrm{mL})$, オキシテトラサイクリン (<0.063〜0.2 $\mu \mathrm{g} / \mathrm{mL})$, オキソ リン酸 $(0.39 \sim 1.0 \mu \mathrm{g} / \mathrm{mL})$ ， カナマイシン $(>128 \mu \mathrm{g} /$ $\mathrm{mL})$, クロラムフェニコール $(1.0 \sim 2.0 \mu \mathrm{g} / \mathrm{mL})$, スル ファモノメトキシン $(128 \mu \mathrm{g} / \mathrm{mL})$, トリメトプリム (32〜 $64 \mu \mathrm{g} / \mathrm{mL})$, ホスホマイシン $(>128 \mu \mathrm{g} / \mathrm{mL})$, およ びニフルスチレン酸ナトリウム（3.12 $\mu \mathrm{g} / \mathrm{mL} ）$ である（反 町 • 前野, 1993b ; Takano et al., 2016)。Ichthyobacterium seriolicida で攻撃したブリ幼魚の経口投与試験では，ア ンピシリン, エリスロマイシン, エンボン酸スピラマイ シン，オキシテトラサイクリン，およびオキソリン酸に 死亡率を低下させる効果が認められている。また，スル ファモノメトキシンは MICが高いものの, 経口投与した 場合には死亡率を顕著に低下させる（反町・前野, 1993b）。したがって，これらの抗菌性物質はBHJの治 療薬として利用できると考えられるが，現在までにいず れの薬凰も承認は受けていない。実際の養殖現場では, レンサ球菌症に対してエリスロマイシンが投薬されてい ることから，これにより BHJの発症が抑えられ顕在化 していないケースもあると考えられる（反町・前野, 1993b)。

\section{残された課題}

BHJ から回復した魚はI. seriolicidaの再感染に対して 強い抵抗性を持つ。また，耐過魚の血清を移入したnaïve 群ではI. seriolicida 攻撃後の死亡率が有意に低下する。さ らに，耐過魚の血清から精製した抗体を naïve 個体の血 清と混合し I. seriolicida 菌体に作用させると古典的補体 活性化経路によって殺菌が生じる（Matsuyama et al., 2018）。すなわち，本菌は特異抗体の誘導によって容易 に防除できるものと考えられる。しかしながら，本菌は FBS を添加した L-15 液体培地であってもわずかにしか 増殖せず，未だ実用的な不活化ワクチンが開発されてい ない。今後，安価で効率の良い培養法を開発することが 課題として残されている。一方で，著者らは，遺伝子組 換え技術を利用した抗原の大量調製技術の確立を目指し, 新たな農林水産政策を推進する実用技術開発事業「遺伝 子情報を利用した難培養性病原体に対するワクチン技術 の開発」において, I. seriolicidaの全ゲノム配列から感染 防御抗原遺伝子を予測し, 組換えサブユニットワクチン の開発を行った。これまでに，感染防御抗原遺伝子を元 に調製した数種類の組換え抗原で有効性を確認している。 こちらのワクチンについても今後の改良と実用化が待た れる。

\section{文献}

lida, T. and M. Sorimachi (1994): Cultural characteristics of the bacterium causing jaundice of yellowtail, Seriola quinqueradiata. Fish Pathol., 29, 25-28.

伊東尚史・毛良明夫 ·村田 寿 ·吉田照豊・境 正・山内 清・山崎義弘・山口登喜夫・宇川正治（2000）：ブリにお ける実験的細菌性溶血性黄疸と酸化ストレス．日本水産学 
会誌, 66, 50-54

前野幸男・中島員洋・反町 稔・乾 靖夫（1995）：養殖ブリ 黄㾝の病態生理. 魚病研究, 30,7-14.

増村和彦・若林久嗣（1977）：人工生産マダイ, クロダイ稚魚 の滑走細菌感染症. 魚病研究, 12, 171-177.

Matsuyama, T., Y. Fukuda, T. Sakai, N. Tanimoto, M. Nakanishi, T. Takano and C. Nakayasu (2017): Clonal structure in Ichthyobacterium seriolicida, the causative agent of bacterial haemolytic jaundice in yellowtail, Seriola quinqueradiata, inferred from molecular epidemiological analysis. J. Fish Dis., 40, 1065-1075.

Matsuyama, T., Y. Fukuda, T. Takano, T. Sakai and C. Nakayasu (2018) : Antibody-mediated bacterial killing of Ichthyobacterium seriolicida in Japanese amberjack. Vet. Immunol. Immunopathol., 203, 73-77.

三井清加・飯田貴次 · 吉田照豊 - 廣野育生 ・青木 宙 (2004)： PCRによるブリ細菌性溶血性黄疸原因菌の検出. 魚病研 究, 39, 43-45.

Sakai, T., H. Murata, M. Endo, K. Yamauchi, N. Tabata and M. Fukudome (1989): 2-Thiobarbituric acid values and contents of $\alpha$-tocopherol and bile pigments in the liver and muscle of jaundiced yellowtail, Seriola quinqueradiata. Agric. Biol. Chem., 53, 1739-1740.

Sakai, T., H. Murata, M. Endo, T. Shimomura, K. Yamauchi, T. Ito, T. Yamaguchi, H. Nakajima and M. Fukudome (1998): Severe oxidative stress is thought to be a principal cause of jaundice of yellowtail Seriola quinqueradiata. Aquaculture, 160, 205-214.

反町稔・前野幸男 - 中島員洋 - 井上潔・乾 靖夫 (1993a）：養殖ブリ“黄㾝症”の原因. 魚病研究, 28, $119-124$

反町 稔・前野幸男（1993b）：ブリ“黄疸症”原因菌の各種薬 剂に対する感受性. 魚病研究, 28, 141-142.

Takano, T., T. Matsuyama, T. Sakai, Y. Nakamura, T. Kamaishi, C. Nakayasu, H. Kondo, I. Hirono, Y. Fukuda, M. Sorimachi and T. lida (2016): Ichthyobacterium seriolicida gen. nov., sp. nov., a member of the phylum 'Bacteroidetes', isolated from yellowtail fish (Seriola quinqueradiata) affected by bacterial haemolytic jaundice, and proposal of a new family, Ichthyobacteriaceae fam. nov.. Int J. Syst. Evol. Microbiol., 66, 580-586.

Takano, T., Y. Nakamura, T. Matsuyama, T. Sakai, Y. Shigenombu, T. Sugaya, M. Yasuike, A. Fujiwara, H. Kondo, I. Hirono, Y. Fukuda and C. Nakayasu (2017): Complete genome sequence of Ichthyobacterium seriolicida JBKA-6 ${ }^{\top}$, isolated from yellowtail (Seriola quinqueradiata) affected by bacterial hemolytic jaundice. Genome Announc., 5, e01574-16.

柳 宗悦・福留 慶・和田和彦 (2016)：魚病総合対策事業（養 殖衛生管理体制整備事業)。平成28年度 鹿児島県水産技術 開発センター事業報告書, pp. 206-213.

和田新平・畑井喜司雄・窪田三郎（1989）：体色黄化を特徵と する養殖ブリの光学顕微鏡所見. 魚病研究, 24, 211-218. 